\title{
Neoproterozoic A-type magmatism in the Western Sierras Pampeanas (Argentina): evidence for Rodinia break-up along a proto-lapetus rift?
}

\author{
E. Baldo, ${ }^{1}$ C. Casquet, ${ }^{2}$ R.J. Pankhurst, ${ }^{3}$ C. Galindo, ${ }^{2}$ C.W. Rapela, ${ }^{4}$ C.M. Fanning, ${ }^{5}$ J. Dahlquist ${ }^{6}$ and \\ J. Murra ${ }^{1}$ \\ ${ }^{3}$ Conicet, Departamento de Geología, Universidad Nacional de Córdoba, 5016 Córdoba, Argentina; ${ }^{2}$ Departamento de Petrología y \\ Geoquimica, Universidad Complutense, 28040 Madrid, Spain; ${ }^{3}$ British Geological Survey, Keyworth, Nottingham NG12 5GG, UK; ${ }^{4}$ Centro de \\ Investigaciones Geológicas, Universidad Nacional de La Plata, 1900 La Plata, Argentina; ${ }^{5}$ Research School of Earth Sciences, The Australian \\ National University, Canberra, ACT 200, Australia; ${ }^{6}$ UNdeC-CRILAR-CONICET, 5301 Anillaco, La Rioja, Argentina
}

\begin{abstract}
A-type orthogne isses of mid Neoproterozoic age $(774 \pm 6 \mathrm{Ma}$, $\mathrm{U}-\mathrm{Pb}$ SHRIMP zircon age), are reported for the first time from the Grenvillian basement of the Western Sierras Pampeanas in Argentina. These anorogenic meta-igneous rocks represent the latest event of Rodinia break-up so far recognized in Grenvillian basement exposures across Andean South America. Moreover, they compare well with A-type granitoids and volcanic rocks
\end{abstract}

along the Appalachian margin of Laurentia (Blue Ridge), thus adding to former evidence that the Western Sierras Pampeanas Grenvillian basement was left on the conjugate rifted margin of eastern Laurentia during Rodinia break-up and the consequent opening of the lapetus ocean.

\section{Introduction}

l'iper (1976) first snggesred that the continental masses were once reunited in a supercontinent at the end of the Mesoproterozoic. Evidence for this supercontinent, that was called Rodinia by McMenamin and McMenamin (1990), has since been grnwing (for reviews see Meert and Torsvik, 2003; Pisarevsky et al., 2003). Amalgamation of Rodinia took place by successive ocean consumption, arc collision and eventually continental collision, resulting in the worldwide Grenville orogeny between ca. 1.3 and 1.0 Ga (Hoffman, 1991). Rodinia subsequently broke up during the Neoproterozoic, but the timing of this process is poorly known. Many continental margins resulting from Rodinia break-up were subsequently involved in younger mobile belts, so that evidences such as extensional structures and syn-rift sedimentary fillings were larigely overprinted by new tectonic fabrics and masked by younger magmatism and metamorphism. A-1 ype granitic rocks however remain as good evi-

Correspondence: Professor Cesar Casquet, Departamento de Petrología y Geoquinica, Universidad Complutense, 28040 Madrid, Spain. Tel.: + 34 913944908; fax: +34 915442535; e-mail: casquet@geo. ucm.es dence for rifting, as they are typical of anorogenic extensional settings (e.g. Eby, 1990), preserve their chemical features unmodified irrespecive of metamorphic grade, and can be readily dated by precise U-Pb geochronology. We report here Neoproterozoic ca. $774 \mathrm{Ma}$ orthogneisses representing volcanic or subvolcanic A-1 ype magmatism in the Grenvillian basement of the Western Sierras Pampeanas in Argentina (Baldo et al., 2005) (Fig. 1a). This magmatism attests to an earlier phase of rifting in Rodinia, during the $200 \mathrm{Myr}$ preceding the opening of the Iapetus ocean (Bartholomew and Tollo, 2004). This event is recognized for the first time in Andean South Amcrica, where remnants of Grenville-age basement are presirved in Colombia, Perú, eastern Bolivia and the Western Sierras Pampeanas of Argentina.

\section{Geological Setting}

Grenville-age basement in the Western Sierras Pampeanas, thoroughly rejnvenated during the Famatinian orogeny in the Early to Middle Ordovician, has been recognized from a number of orthogneisses dated at ca. 1.0-1.1 Ga (Dalla Salda and Varela, 1984; McDonough et al., 1993; Pankhurst and Rapela, 1998), detrital zircon ages (casqlet et al., 2001), an ophiolire complex of ca. $1.2 \mathrm{Ga}$ (Vujovich et al.,
2004), massif-iypi anorthosites of ca. $1070 \mathrm{Ma}$ (Casquet et al., 2005a) and granulite facies metamorphism of ca. $1.2 \mathrm{Ga}$ (Casquet et al., 2006). This orthogneissic basement is overlain by an epeiric merasedimentary sequence of carbonate and siliciclastic rocks the Difunta Correa sedimentary sequence of Baldo et al., 1998), which is late Neoproterozoic in age (Cialindo et al., 2004) and contains detrital zircons of likely Gondwana provenance (Rapela et al., 2005).

The Western Sierras Pampeamas Grenvillc-agc outcrops are generally considered to represent the basement of the Precordillera (or (nyania) terrane, i.e. an exotic continental block that allegedly rifted away from the Ouachita embayment of Laurentia in late Neoproterozoic-Farly Cambrian times, and collided with the protoAndean margin of Gondwana in the Ordovician to produce the Famatinian orogeny (for a review of the Precordillera terrane hypothesis, see Thomas and Asini, 2003; Ramos, 2004). The terrane has a passive margin carbonate sequence of early Cambrian to early Ordovician age, exposed in the Argentine Precordillera to the west of the Sierras Pampeanas (Fig. 1a), which contains faunas akin to those of the late Neoproterozoic eastern Laurentia rifted margin. Alloch thoneity of the Western Sierras Parrpeanas basement has, however, 


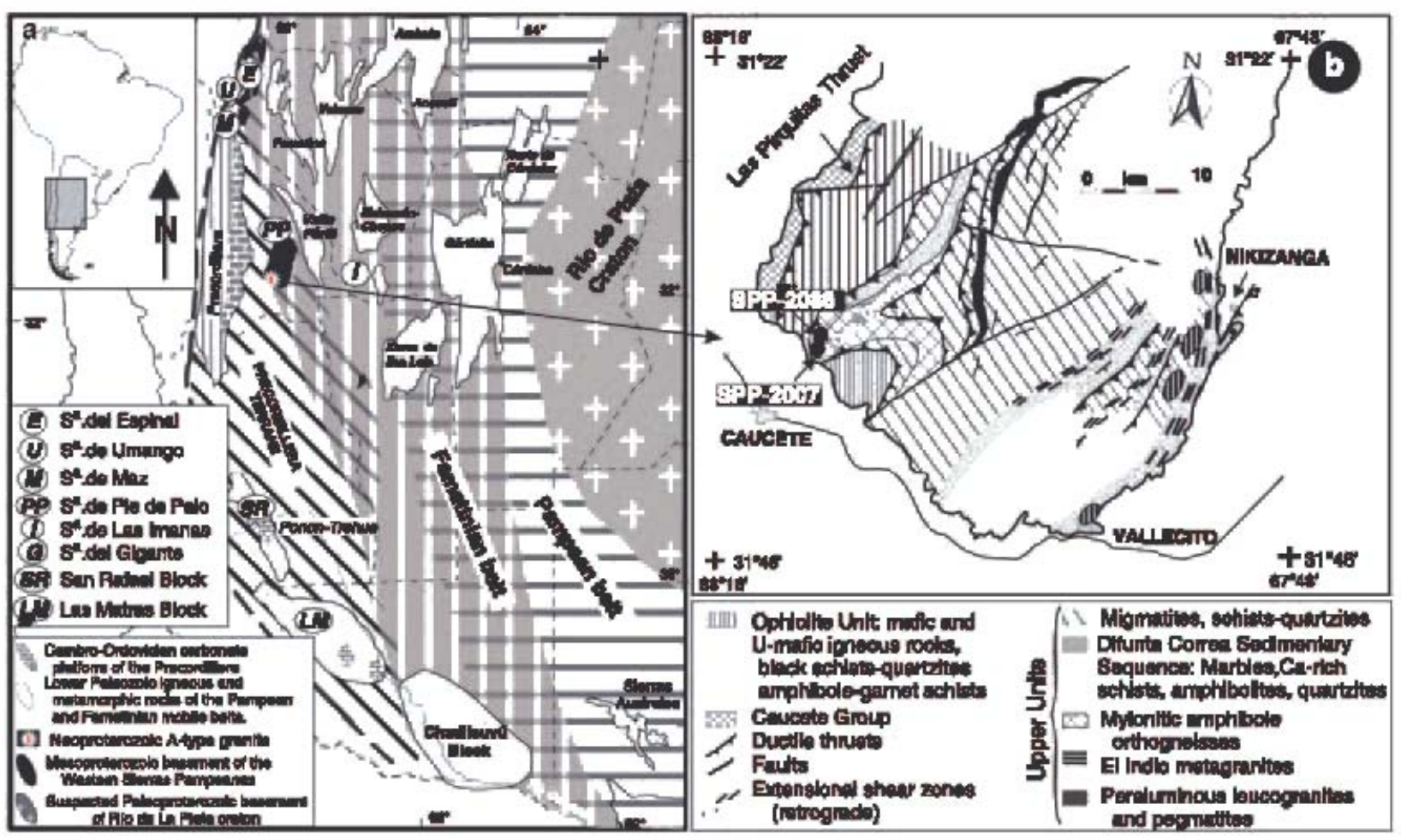

Fig. 1 (a) Sketch map shøwing location of the Siesra de Pie de Pal•, Western Sierras Pampeanas, the Precordillera Terrane and main or ogenic belts. (b) Geological map of southern Siesra de Pie de Palo, and sampling location.

been recently questioned (e.g. Galinde et al., 2014).

The Sierra de Pie de Fale (Fig. 16) is one of the Western Sierras Pampeanas where Grenville-age recks were first recegnized. The sieira censists of stacked nappes thrust westwards during the Famatinian eregeny: each ene consists of beth Grenville-age basement and the Difunta Cerrea sedimentary sequence, which underwent penetrative defermation (felding, foliatien develepment and ductile shearing) and relatively high-pressure low-temperature Famatinian metamerphism. The nappes rest upen the almest unmetamerhesed Precerdillera passive maIgin sequence of early Cambian age (Galinde et al., 204) belew the Pirquitas basal thrust ( $\mathrm{Ra}$ mes et al., 1996). The leweimest nappe centains a Grenville-age ephi- lite of ca. 1.2 Ga (Vujevich et al., 204; and references therein). Abeve this nappe is a wide shear zene where rocks of the Difunta Correa metasedimentary sequence and A-type erthegneisses are thereughly interleaved. Relative age relationships are cenfused by the streng defermation.

\section{Sampling and Petrography}

Twe samples of a mylenitic er the gneiss (SPP-2007 and SPF-2086) were cellected at the meuth of the Quebra-

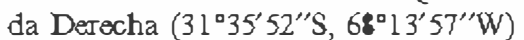
(Fig. 1b), for chemical analysis (majer and trace elements) and isetepe (Sr and Nd) geechemistry. SPF-2007 was chesen fer U-Pb SHRIMP zircen dating. This er thegneiss is interleaved with epidete-bearing gamet micaschists (Mtz, Ms, Bt, Pl, Grt, Ep, \pm Amph; mineral abbreviations as in Kretz, 1983), black quartzites (Qtz, P1, Bt, $\pm \mathrm{Ms}$ ), amphibele-gamet schists (Ctz, P1, Amph, Git, Ep, Ms, \pm Bt), gamet amphibelites (H), P1, Grt, EP, ere minerals) and miner marble.

The er thegneiss censists of $\mathbf{Q t z}, \mathrm{K}$ fs (Ars, $\left.\mathrm{Ab}_{4-5}\right), \quad \mathrm{Pl}\left(\mathrm{An}_{3}, \mathrm{~A} b_{\eta}\right), \mathrm{Bt}$ $\left(X_{\mathrm{Fe}}-8.83, \quad \mathrm{~F}-0.43 \%\right)$, Grt $\left(\right.$ Alm $_{36-40}, \mathrm{GIs}_{35.44}, \mathrm{SP}_{18-24}$, And $_{2.3-6}$, Py•.5-7), Fe-pargasite $\left(\mathrm{K}_{2}-2.2\right.$ $\left.2.6 \% ; \mathrm{Na}_{2}-1.92 .2 \%\right)$, Ep $\left(\mathrm{Ps}_{42}\right)$, Ttn, Aln, Zm, Mnz, Ap, Py and Mag. Representative chemical compositions of minerals are shewn in Table 1 . The gamet contains inclusions of epidete, quartz and plagieclase; its high $\mathrm{Mn}$ content might in itself suggest an igneeus erigin, but as the everall reck compesition is metalumineus it is mere likely that it fermed threugh metameiphic reactions. Garnet amphibele theimemetry (Ravna, 200) provides $T$-values between 620 and $550^{\circ} \mathrm{C}$, but values obtained from garnet bietite exchange thermemetry (Heldaway, 2001) are in the range of $40041{ }^{\circ} \mathrm{C}$

Texturally the enthegneiss censists of $\sigma$-type peiphyeclasts of mainly pinkish K-feldspar (1 $3 \mathrm{~cm}$ cuystals) and medium-grained plagieclase, garnet, epidete and amphibele, all wrapped areund by a feliated finegrained dark groundmass of dynamically reciystallized quartz and bietite (Fig. 2). Cempesite S-C' feliations (Fig. 2) and $\sigma$-type linematic markers suggest that relative mevement within the shear zene was tep-te-the-seuthwest (present ceordinates). Younger -pen felds of variable size with almest herizental $N 80^{\circ} \mathrm{E}$ axes are commen in this part of the sierra.

\section{Geochemistry}

Chemical analyses (Table 2) were perfermed at ACTLABS (Canada). SI 
Table 1 Repres tative chemical compesit on of minerals of orth $\bullet$ gneiss SPP-2ఱ?.

\begin{tabular}{|c|c|c|c|c|c|c|c|c|c|c|c|}
\hline$w t \%$ & Grt & & Bt & & $\mathbf{P I}$ & & Kfs & & $\mathrm{Hbl}$ & & $E p$ \\
\hline$\overline{\mathrm{SiO}_{2}}$ & 37.37 & & 35.76 & & 66.27 & & 63.71 & & 37.56 & & 36.41 \\
\hline $\mathrm{Ti}_{2}$ & 14 & & 246 & & 111 & & 11 & & 46 & & 105 \\
\hline $\mathrm{Al}_{2} \omega_{3}$ & 20.46 & & 14.57 & & 2 & & 18.51 & & 13.8 & & 22.48 \\
\hline $\mathrm{Cr}_{2} \mathrm{O}_{3}$ & t. & & $\bullet 1$ & & +4 & & 14 & & 183 & & 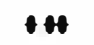 \\
\hline $\mathrm{FeO}$ & $2 * 1$ & & 28.55 & & 111 & & $t .1 t$ & & 28.31 & & 13.3 \\
\hline $\mathrm{Mn} \bullet$ & $8 * 1$ & & +42 & & 14 & & te & & $t .5$ & & $\bullet 35$ \\
\hline $2 n \bullet$ & 1.4 & & +12 & & tet & & 14 & & tet & & 14 \\
\hline MgD & .16 & & 346 & & 11 & & $+\infty$ & & 206 & & 113 \\
\hline tol & 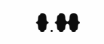 & & 14 & & 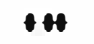 & & เ.17 & & t* & & +4 \\
\hline Sro & 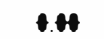 & & +4 & & 1.13 & & 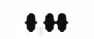 & & t* & & t \\
\hline Cal & 14.58 & & 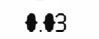 & & .72 & & tet & & $1+3 t$ & & 23.56 \\
\hline $\mathrm{Na}_{2}$ & th & & 107 & & 11.56 & & - 31 & & 2.24 & & $\bullet 3$ \\
\hline $\mathrm{K}_{2} \mathrm{O}$ & 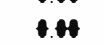 & & 58 & & t.1 & & 16.42 & & 2.28 & & t \\
\hline $\mathrm{F}$ & $\bullet 12$ & & 42 & & 14 & & $\boldsymbol{*}$ & & +22 & & 10 \\
\hline $\mathrm{Cl}$ & th & & $\omega$ & & to & & H & & $+\infty$ & & to \\
\hline \multirow[t]{2}{*}{ Total } & $1 \boldsymbol{H}$ & & 95.78 & & 99.24 & & 94.22 & & 97.31 & & 1643 \\
\hline & $120 x$ & & $240 x$ & & $320 x$ & & $320 x$ & & $230 x$ & & $12.5 \mathrm{Ox}$ \\
\hline$\overline{\mathrm{TSi}}$ & 2.064 & $\overline{\mathrm{Si}}$ & 6.44 & $\overline{\mathrm{Si}}$ & 11.729 & $\overline{\mathrm{Si}}$ & 11.916 & $\overline{\mathrm{Si}}$ & 6.721 & $\overline{\mathrm{Si}}$ & 2484 \\
\hline TAI & $\bullet .36$ & $A l^{N}$ & $2 . H$ & Al & 4.24 & Al & 478 & $A l^{N}$ & 1.27 & $A l^{N}$ & .516 \\
\hline$\left.A\right|^{B 1}$ & 1.675 & $\left.A\right|^{v 1}$ & 1.878 & $\mathrm{Ti}$ & * 1 & $\mathrm{Ti}$ & t.41 & $\left.A\right|^{v 1}$ & 1.477 & $\left.A\right|^{V 1}$ & 1.331 \\
\hline $\mathrm{Ti}$ & - & $\mathrm{T}_{1}$ & .312 & $\mathrm{Fe}^{2}$ & 0117 & $\mathrm{Fe}^{2}$ & *15 & $\mathrm{Cr}$ & 144 & $\mathrm{Ti}$ & 143 \\
\hline $\mathrm{Cr}$ & +42 & $\mathrm{Fe}^{2}$ & 4. 163 & $\mathrm{Mn}$ & t.046 & $\mathrm{Mn}$ & - & $\mathrm{Ti}$ & .062 & $\mathrm{Fe}^{3}$ & 1.337 \\
\hline $\mathrm{Fe}^{2}$ & 1.327 & $\mathrm{Cr}$ & **1 & $\mathrm{Mg}$ & 1.43 & $\mathrm{Mg}$ & 0.040 & $\mathrm{Mg}$ & - 548 & $\mathrm{Cr}$ & tet \\
\hline $\mathrm{Mg}$ & t.18 & $\mathrm{Mn}$ & 0.45 & Ca & 0.4s & Ba & *12 & $\mathrm{Fe}^{2}$ & 4.237 & $M n$ & 102 \\
\hline $\mathrm{Mn}$ & +538 & $\mathrm{Mg}$ & 1.266 & $\mathrm{Sr}$ & •.4\% & $\mathrm{Sr}$ & 0.040 & $M n$ & $\bullet 75$ & $\mathrm{Mg}$ & +43 \\
\hline $\mathrm{Ca}$ & 1.23 & $2 \pi$ & $t+1$ & Ca & - 137 & Ca & 0.040 & Ca & 1506 & Ca & 1.722 \\
\hline $\mathrm{Na}$ & - & Ba & t.446 & $\mathrm{Na}$ & 3.068 & $\mathrm{Na}$ & t.113 & Ca & 1.456 & $\mathrm{Na}$ & 143 \\
\hline Alm & 42.51 & Ca & t.45 & $k$ & $\bullet+22$ & $k$ & 3.918 & $\mathrm{Na}$ & .776 & $k$ & thet \\
\hline Grs & 39.68 & $\mathrm{Na}$ & +22 & $A_{n}$ & 3.3 & Or & 97.2 & $k$ & .52 & Ps & 42 \\
\hline Py & $\bullet 5$ & $k$ & $2 \div 51$ & & & & & & & & \\
\hline Sps & 17.23 & $\mathrm{xMg}$ & t.18 & & & & & & & & \\
\hline
\end{tabular}

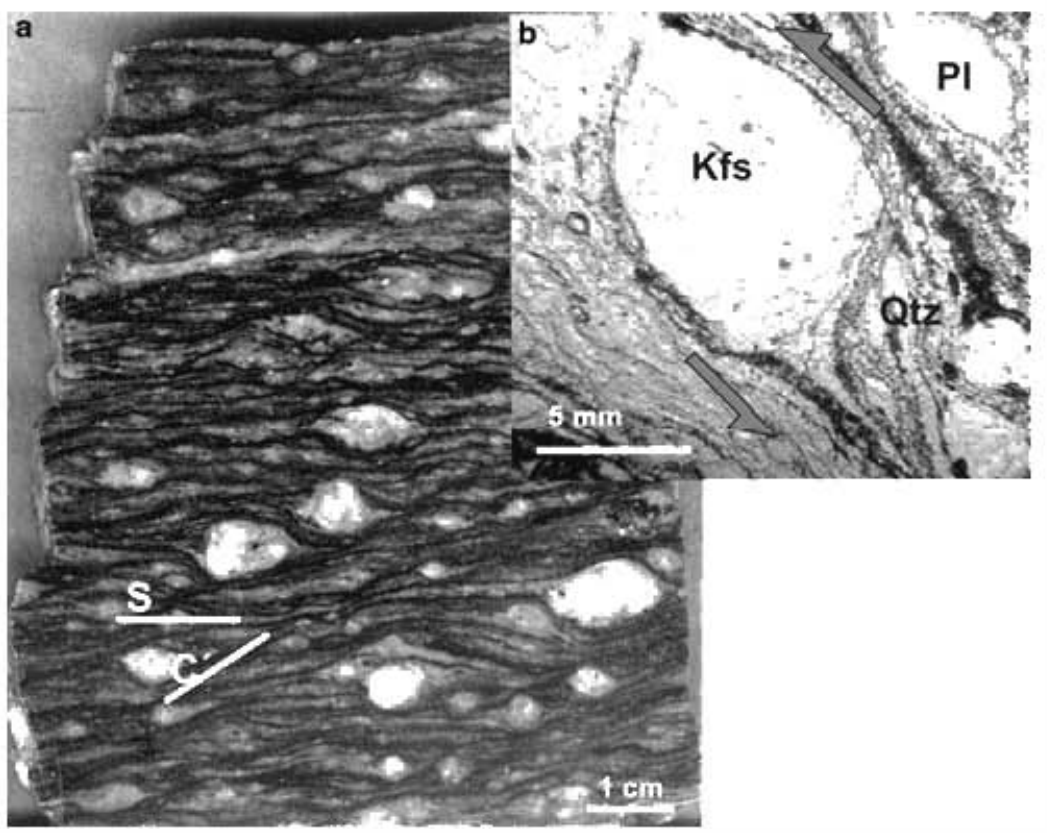

Fig. 2 (a) Mylonitic texture of SPP-2ఱ? orthøgneiss with S-C'c omposite foliations (section parallel to $\mathrm{L}_{\text {myl }}$ ). (b) Asymmetric $\mathrm{K} f \mathrm{~s}$ porphyreclasts in a fine-grained groundmass of dynamically recrystallized quartz and biot:te.
Table 2 Representative chemical and isotopic compositions of mylonitic orthogneisses from Siema de Pie de Palo.

\begin{tabular}{|c|c|c|}
\hline wot $\%$ & SPP-2007 & SPP-2085 \\
\hline $\mathrm{SiO}_{2}$ & 745 & 32.17 \\
\hline $\mathrm{Ti}_{2}$ & $\bullet 26$ & 4 \\
\hline $\mathrm{Al}_{2} \mathrm{O}_{3}$ & 12.25 & 11.91 \\
\hline $\mathrm{Fe}_{2} \mathrm{O}_{3}$ & 2.95 & 4.26 \\
\hline $\mathrm{Mn} \bullet$ & 105 & 107 \\
\hline $\mathrm{Mg} \bullet$ & 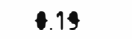 & 138 \\
\hline Cal & 1.48 & 1.61 \\
\hline $\mathrm{Na}_{2} \bullet$ & 3.32 & 3.45 \\
\hline $\mathrm{K}_{2}$ & 4.33 & 4.15 \\
\hline $\mathrm{P}_{2} \mathrm{O}_{5}$ & 1.5 & $\bullet 11$ \\
\hline$L \bullet$ & .42 & +44 \\
\hline Total & 998 & 99 \\
\hline Ba & 565 & $\$ 11$ \\
\hline$R b$ & $\$ 2.41$ & 114 \\
\hline $\mathrm{Sr}$ & 65.8 & $1 \%$ \\
\hline Y & 52.4 & 644 \\
\hline $2 r$ & 338 & 516 \\
\hline $\mathrm{Nb}$ & 221 & 29.8 \\
\hline Th & 988 & 118 \\
\hline $\mathrm{Pb}$ & 24 & 23 \\
\hline Ga & 23 & 25 \\
\hline $2 \pi$ & 16 & 71 \\
\hline V & $\bullet$ & 10 \\
\hline $\mathrm{Hf}$ & 9.7 & 141 \\
\hline Cs & 16 & 1.1 \\
\hline Se & 4 & $\&$ \\
\hline Ta & 1.62 & 2.34 \\
\hline$C_{0}$ & 2 & 4 \\
\hline Be & 3 & 4 \\
\hline u & 3.87 & 3.36 \\
\hline$w$ & 1.2 & 1.9 \\
\hline
\end{tabular}

PEE (p.p.m.)

\begin{tabular}{|c|c|c|}
\hline La & 57.8 & 54.6 \\
\hline $\mathrm{Ce}$ & 137 & 123 \\
\hline $\mathbf{P r}$ & 15.7 & 151 \\
\hline Nd & $6+36$ & 571 \\
\hline $\mathrm{Sm}$ & 11.87 & 13. \\
\hline Eu & 1.39 & 2.25 \\
\hline Gd & 11.4 & 12.4 \\
\hline Tb & 183 & 24 \\
\hline y & $1 * 3$ & 12.2 \\
\hline Ho & 2.5 & 2.3 \\
\hline $\mathrm{Er}$ & 6.39 & 78 \\
\hline $\operatorname{Tm}$ & 1.4 & 1.22 \\
\hline$Y b$ & 6.35 & 74 \\
\hline Lu & 188 & 1.2 \\
\hline Sum & 3244 & 317.5 \\
\hline \multicolumn{3}{|l|}{ isotopic matios } \\
\hline$S m / N d$ & +11066 & +2277 \\
\hline${ }^{143} \mathrm{Sm} / /^{141} \mathrm{Nd}$ & t.1184 & .1376 \\
\hline 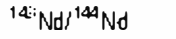 & -512457 & $\bullet 5125 \bullet 2$ \\
\hline$\left.{ }^{14:} \mathrm{Nd}\right\}^{144} \mathrm{Nd}\{374)$ & .511854 & .511893 \\
\hline$\varepsilon^{2} d_{334}$ & 4.1 & 4.9 \\
\hline $\operatorname{Tdm}\{\mathrm{Ga}\}$ & 106 & 149 \\
\hline Rbis $S_{\text {[iwot) }}$ & 1.4638 & 1.4556 \\
\hline${ }^{3} \mathrm{Rb} /{ }^{\infty} \mathrm{Sr}$ & 4.776 & 3.62 \\
\hline${ }^{93} \mathrm{SH}^{36} \mathrm{Sr}$ & เ. 748154 & .734428 \\
\hline${ }^{87} \mathrm{~S}^{36} \mathrm{Sr}_{(374)}$ & เ.7*3*91 & 0704589 \\
\hline$\varepsilon \mathrm{S}_{334}$ & -6 & -42.4 \\
\hline
\end{tabular}




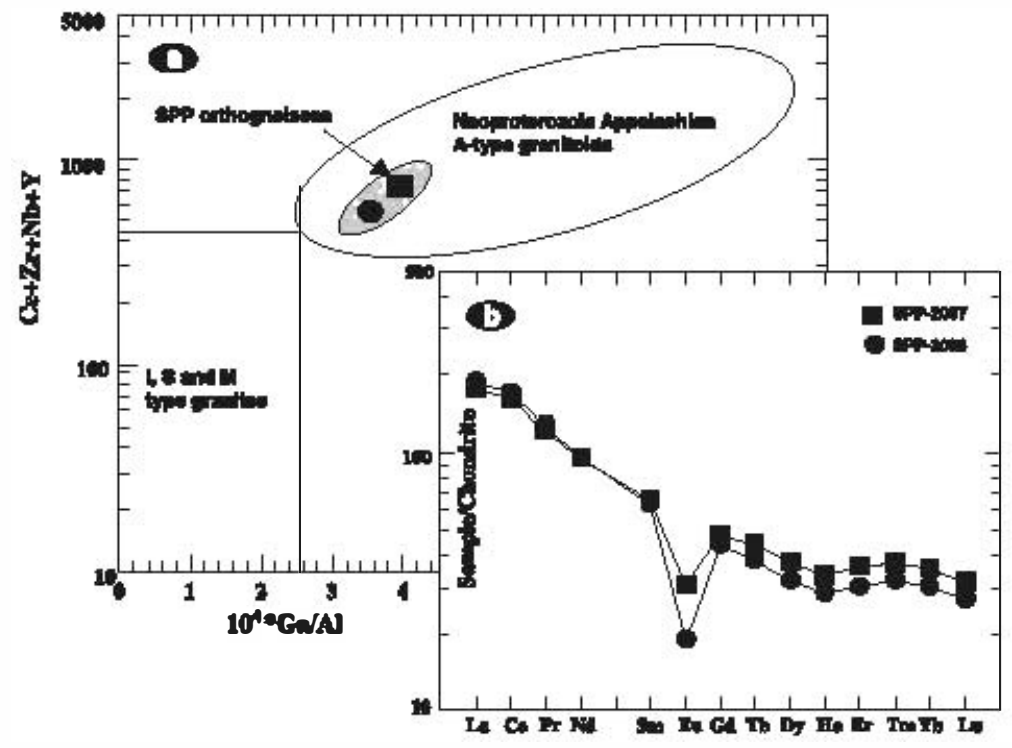

Fig. 3 (a) Fot of $(\mathrm{Ce}+\mathrm{Zr}+\mathrm{Y})$ vs. $10^{4} \times \mathrm{Ga} / \mathrm{Al}$ for Neoproterozoic A-type granites

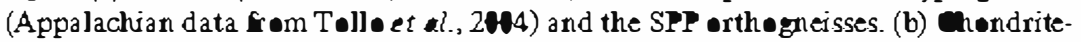
normalizad REE plot of SPP orth gneisses.

and $\mathrm{Nd}$ isetepe compesitions were ebtained at the Geochrenelegy and Isetepe Geechemistry Centre at the Universidad Complutense of Madrid.

Chenically the erthegneisses are metalumineus acid recks $\left(\mathrm{SiO}_{2}-\right.$ $7274 \%$; ASI - 1.97 ), but with a relatively high agpaitic index (1.85 and 0.88 ), high tetal alkalis (7.6 and $8.2 \%)$ and a ratie $\mathrm{Fe}_{2} \mathrm{O}_{\text {3totel }} / \mathrm{Mg}$ of 11.2 and 15.5. These geochemical features are characteristic of A-type magmatism (Eby, 1990, 1992). This classification is strengthened by the Ielatively high values of the $1 *^{*} \mathrm{Ga}$ Al ratie (3.5 and 3.9), aleng with high cencentrations of HFS elements $Y$ (52 64 p.p.m.), Nb (22 3 p.p.m.), Ta (1.62 2.34 p.p.m.), Ga (23 25 p.p.m.) and $\mathrm{ZI}$ (336 516 p.p.m.) (Fig. 3a). As the alkali centent may reflect the effect

metamerphism, high-silica igneeus recks are eften classified using HFS element abundances: Iow-ZI recks (>300 p.p.m.) are termed 'subalkaline' whereas high-ZI rocks ( $>350$ p.p.m.) are classed as peralkaline' (Leat et al., 1986). The high Zr centent of the erthegneisses clearly indicates an alkaline affinity for the igneous preteliths. These rocks are moderately eniched in LREE (La) $[\mathbf{Y b}]_{\mathbf{N}}-4.96 .1$ ) and show a remarkable Eu-negative anemaly ( $\mathrm{Eu} / \mathrm{Eu}^{*}-$ - 36 .54) (Fig.36), suggesting plagieclase fractionation. Further- mere, their REE pattern is very similar to that reperted for A-type granites (e.g. Scheepers, 200); Telle et al., 204; Dahlquist et al., 206). ${ }^{143} \mathrm{Nd} /{ }^{144} \mathrm{Nd}$ and ${ }^{87} \mathrm{Sr} /{ }^{86} \mathrm{Sr}$ values at the age of caystallization of $774 \mathrm{Ma}$ (see belew) (Table 2) are between - 511854 and 0.511893 , cerrespending to a mean $\varepsilon \mathrm{Nd}_{n 4}$ value of +4.2 , and between 0.7031 and 0.7006 respectively. The multi-stage Nd medel age ( $T_{D M}$ ) is $160 \mathrm{Ma}$. Rb Si systematics in metameiphic recks are highly susceptible te disturbance, and the lewer ${ }^{87} \mathrm{Sr} /{ }^{86} \mathrm{Sr}$ value (belew the Bulk Earth value of $\$ .7036$ at the caystallization age) might result frem subselidus alteration during the everpinting by Famatinian defermation and metamerphism. The ether value, and the twe Nd isetepe compesitions, are taken as indicative of a primitive source, which is net uncemmen for A-type magmatism (e.g. Kebede and Koberl, 203; Mushlin et al., 203).

\section{U.Pb Geochronology}

A heavy mineral cencentrate was prepared from sample SPF-2007 at NERC lsetepe Geesciences Laberat-1y, Keywerth, by disc-milling and panning, follewed by standard heavy liquid and magnetic procedures. Appreximately 100 zircen grains were hand-picked from the mineral cencentrate, mounted in epexy together with chips of reference zircens $\mathrm{FCl}$ and SLl3, greund appreximately half-way through and pelished. Reflected and transmitted light phetemicregraphs, and cathede-luminescence (CL) SEM images, were used to decipher the internal structures of sectioned grains and te target specific areas within the zircens.

U-Th-Pb zircens analyses were made using SHRIMP II, each analysis censisting of six scans through the mass range. The data were reduced in a manner similar to that described by Williams (1998, and referances therein), using the SQUID Excel Macre of Ludwig (200).

Zircens from sample SPF-20? range frem euhedral grains with pyramidal teminations to subhedral forms with semewhat ragged terminatiens. The grains are mestly elengate with an average length/breadth ratie of abeut $2: 1$. A number of grains have tube-like central cavities that are commenly ebserved in rapidly crystallized zircen fiem a velcanic te subvelcanic setting. The CL images reveal mestly zened igneeus zircen, theugh internal discentinuities are present and little-te-unzened contral areas are anether feature commenly seen in velcanic crystals. Buight luminescent nims are interpreted as part of the same single igneeus cuystallization event. However, some mere ragged grain shapes reflect medification during metameiphism, even theugh ne significant new zircen developed. Measurements were made by analysing 14 areas; the luminescent iims were tee thin te permit analysis. A summary of the results is listed in Table 3 and shewn in a Tera Wasserburg plet (Fig.4b). Uncerrected data mestly fall in a tight greup clese te Cencerdia, signifying that cemmen Po centents are very lew. Ignering ene low apparent age $(74 \mathrm{Ma})$, the :mp-cerrected ${ }^{206} \mathrm{~Pb} /{ }^{738} \mathrm{U}$ results yield a censistent mean of $774 \pm$ $6 \mathrm{Ma}(95 \%$ cenfidence limit including uncertainty in the reference zircen $\mathrm{U} /$ Po ratie calibration; MSWD - 175 ). This age is taken te represent the crystallization of the igneeus protelith of the erthegneiss.

\section{Discussion}

The significant time gap between the end of the Grenville-age eregeny in 
Table 3 U-Pb SHRIMP data for zircons in SPP-2007.

\begin{tabular}{|c|c|c|c|c|c|c|c|c|c|c|c|c|c|c|}
\hline \multirow{2}{*}{$\begin{array}{l}\text { Grain } \\
\text { spot }\end{array}$} & \multirow{2}{*}{$\begin{array}{l}U \\
(p . p . m .)\end{array}$} & \multirow{2}{*}{$\begin{array}{l}\text { Th } \\
\text { (p.p.m.) }\end{array}$} & \multirow[b]{2}{*}{ Th/U } & \multirow{2}{*}{$\begin{array}{l}P b{ }^{*} \\
\text { (p.p.m.) }\end{array}$} & \multirow[b]{2}{*}{${ }^{204} \mathrm{Pbd}{ }^{206} \mathrm{~Pb}$} & \multirow[b]{2}{*}{$\mathbf{f}_{206} \%$} & \multicolumn{4}{|l|}{ Total } & \multicolumn{2}{|l|}{ Radiogenic } & \multicolumn{2}{|l|}{ Age (Ma) } \\
\hline & & & & & & & $\left.{ }^{203} \mathrm{~Pb}\right)^{206} \mathrm{~Pb}$ & $\pm 1 \sigma$ & ${ }^{238} \mathrm{U} / /^{206} \mathrm{~Pb}$ & $\pm 1 \sigma$ & $\left.{ }^{206} \mathrm{pb}\right)^{238} \mathrm{U}$ & $\pm 1 \sigma$ & $206 \mathrm{~Pb})^{238} \mathrm{U}$ & $\pm 1 \sigma$ \\
\hline 1.1 & 212 & 54 & 0.25 & 2 & 0.0००157 & 0.21 & 0.0669 & 0.0H? & 7835 & 0.129 & 0.1274 & 0.0021 & 372. & 12.0 \\
\hline 1.2 & 305 & 22 & $\bullet 27$ & 29 & - 040285 & $\bullet .17$ & 10006 & tons & 7806 & $\bullet .105$ & .1264 & $* * 13$ & 767.4 & 9.6 \\
\hline 2.1 & 374 & 125 & $\bullet 33$ & 37 & t mo1t? & $<+1$ & 1.045 & 10046 & 7793 & t.492 & 1.1284 & $* 15$ & 378.3 & 8.7 \\
\hline 31 & 45 & 15 & $\bullet 33$ & 4 & - & $<1$ & 10006 & $* 25$ & 7.913 & +44 & .1265 & +0064 & 767.7 & 36.8 \\
\hline 4.1 & 175 & 47 & +27 & 17 & t $\cos 285$ & $t .2$ & 1.0654 & t coses & 7824 & $\bullet .113$ & t.1278 & **13 & 375.2 & 116 \\
\hline 5.1 & 113 & 29 & $\bullet 25$ & 11 & t 4016 & $\bullet .17$ & 10006 & $* 11$ & 7731 & $\bullet .113$ & เ.1291 & $* 41$ & 782.3 & 18.8 \\
\hline 6.1 & 218 & $6 t$ & $\bullet 27$ & 21 & - & $\bullet .17$ & +006 & tens & 7062 & $\bullet .111$ & $\bullet .1254$ & คH18 & 761.5 & 14.1 \\
\hline 7.1 & 37 & 123 & 133 & 36 & เ.4พ13 3 & 116 & 14657 & tH4 & $7.76 t$ & $\$ .14$ & +1288 & ค.ม17 & 784.5 & $\$ 5$ \\
\hline 8.1 & 46 & 11 & $\bullet 25$ & 4 & t.41248 & $\bullet .27$ & 1.0674 & $* 14$ & 7727 & $\bullet .156$ & $\bullet 1241$ & * 26 & 722.6 & 14.9 \\
\hline$\$ 1$ & 12 & 3 & $\bullet 25$ & 12 & - tente 4 & 116 & 1.0665 & *13 & 7.799 & $\bullet .116$ & $\bullet 1245$ & t*2t & 7851 & 11.2 \\
\hline $1 *$ & 292 & 106 & .36 & 29 & - MP12 & 1.85 & 1.0656 & +0046 & 7717 & $\operatorname{lng} 2$ & $\bullet .1245$ & $* 416$ & 785.2 & 8.9 \\
\hline 11 & 257 & 16 & $\bullet 33$ & 25 & คคม2 256 & 1.83 & 1.0654 & +0006 & 7.940 & $t .14$ & .125 & $* 16$ & 364.4 & $\$ 1$ \\
\hline 12 & 113 & 24 & +2 & 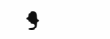 & t & 102 & .0654 & +0006 & 8.22 & $\bullet .127$ & t.1216 & *11 & $74 t$ & 14. \\
\hline 13 & 211 & 58 & 128 & 2 & 1.049026 & 107 & 1.0658 & +0006 & 7.952 & $\bullet .102$ & .1257 & $* 16$ & 7631 & 9 \\
\hline
\end{tabular}

1 Uncertainties given atthe lo level

$2 \mathrm{f}_{206} \%$ denotes tie perentage of ${ }^{206} \mathrm{~Pb}$. that is ormmon $\mathrm{Pb}$

3 Comection for common $\mathrm{Pb}$ made using the measured ${ }^{230} \mathrm{U} /{ }^{206} \mathrm{~Pb}$ and ${ }^{203} \mathrm{~Pb} /{ }^{206} \mathrm{~Pb}$ ratios following Tera and Wasserburg (1972) as outlined in Will lams (1998)

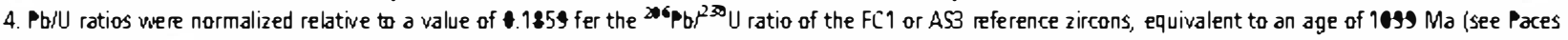
and Miller, 1943)

$P b$ * - Radiogenic Pb

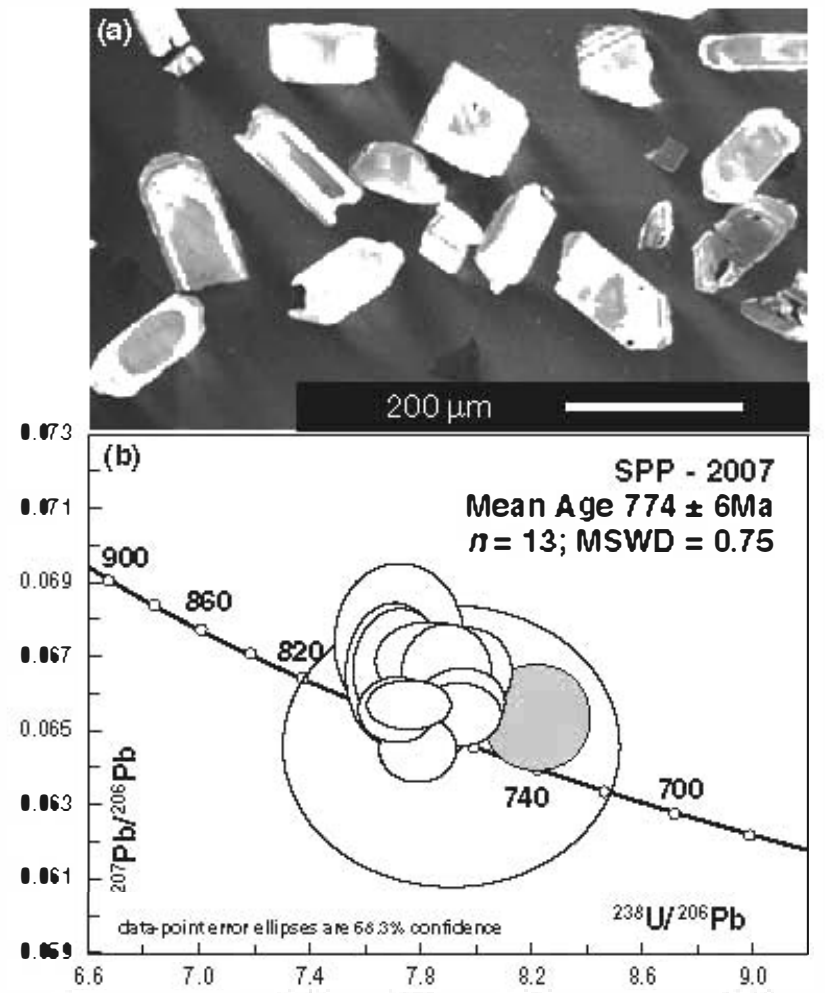

Fig. 4 (a) Cathed-Juminescence images of SPP-2\%7 zircons shøwingunzoned cores, magmatic esclllatory-zoned evergrowths and a thin luminescent $r$.m. (b) TeraWasserburg diagram of the full dataset showing exror elfipses at $68.3 \%$ confidence limits for igneous cores and rims.

the Westem Sierras Pampeanas and the A-type magmatism in the Sierra de Pie de Pale, attests to a pest-regenic continental Iifing setting at $774 \pm$ $6 \mathrm{Ma}$. This is the youngest aneregenic magmatic event of Neepreterezeic age se far recegnized in this part of the pre-Andean basement. Older igne- us events that were prebably alse pest-eregenic have been recerded frem the Western Sien ras Pampeanas basement at ca. 1 $\mathrm{Ma}$ (massif-type anerthesites; Casquet et al., 205a) and ca. $845 \mathrm{Ma}$ (Casquet et al., 2056), perhaps representing discrete Iifting events during pretracted breakup of Redinia. The A-type erthegneisses are thus probably indicative of the firal stage of break-up and censtitute the first indication of this event se far recegnized in Seuth America, where remn ants of Grenville-age basement exist in Celembia, Ferú, eastem Belivia and Argentina.

The timing of break-up acress the Rodinia supeicentinent is still peorly known in detail. Hewever, ages between 850 and $700 \mathrm{Ma}$ have been recerded for extensional mafic magmatism, bimodal magmatism, and A-type er ether granites from many different

gins, and are similarly censidered indicative of Rodinia break-up. Typical examples of this are in the Canadian Aictic (Shellnutt et al., 2044), southern and central Austialia (Wingate et al., 1998), Baltica (Fease and Begdaneva, 2003), the Scandinavian Caledenides, Scetland and Taimyr (Paulssen and Andreassen, 2002; Caweed et al., 2044), the Yangtze craten and Seuth China (Wenli et al., 
2003), the North China block (Zhai et al., 2003), South Korea (Lee et al., 2003) and eastern Egypt (Loizembauer et al., 2001).

Of particular relevance to our case is the Neoproterozoic A-type magmatism recorded along the Appalachian margin of Laurentia in the Blue Ridge province. In recent paleogeographical reconstructions of Rodinia (e.g. Loewy et al., 2003), eastern Laurentia is placed alongside Amazonia, whose southern extension (present coordinates) is represented by the Arequipa-Antofalla block of Perú, northern Chile and Argentina, accreted to Amazonia during the Grenville age-equivalent Sunsas orogeny (Loewy et al., 2004), and probably also by the Western Sierras Pampeanas Grenvillian basement (Casquet et al., 2005a,b). A remarkable event of A-type granitic magmatism and bimodal volcanism has been long recognized in the Blue Ridge province of Virginia and North Carolina with crystallization ages between 765 and $680 \mathrm{Ma}$ (Tollo et al., 2004, and references therein). Protracted north-migrating rifting accompanied by A-type magmatism, continued along the Appalachian margin of Laurentia until $572-564 \mathrm{Ma}$ when Iapetus was created (Bartholomew and Tollo, 2004). The older Blue Ridge ages are slightly younger than the age determined here for the Sierra de Pie de Palo orthogneisses. Thus, in the hypothesis of an AmazoniaArequipa Antofalla-Western Sierras Pampeanas-eastern Laurentia connection within the Rodinia supercontinent, the Sierra de Pie de Palo A-type orthogneisses might thus represent an earlier rifting event still farther south. This similarity between the two margins is additional to the already recognized parallels between massif-type anorthosites in the Western Sierras Pampeanas and the Appalachian Blue Ridge and the Piedmont provinces (Casquet et al., 2005a). The evidence presented here thus strengthens the hypothesis that the Appalachian margin of Laurentia and the western margin of Amazonia - and its southern extension into the Western Sierras Pampeanas - were conjugate-rifted margins in the mid Neoproterozoic. Drifting across these margins subsequently led to the opening of the Iapetus ocean.

\section{Acknowledgements}

Financial support for this paper was provided by a Spanish MEC grant (BTE20011486; CGL2005-02065/BTE) and Argentine public grants (FONCYT PICT 0710735; CONICET PIP 02082; CONICET PEI-6275). R.J.P. acknowledges an NERC Small Research Grant.

\section{References}

Baldo, E.G., Casquet, C. and Galindo, C., 1998. Datos preliminares sobre el metamorfismo de la Sierra de Pie de Palo, Sierras Pampeanas Occidentales (Argentina). Geogaceta, 24, 39-42.

Baldo, E., Casquet, C., Pankhurst, R.J., Rapela, C.W., Galindo, C., Dahlquist, J., Murra, J. and Fanning, C.M., 2005. Neoproterozoic A-type magmatism in the basement of the Precordillera terrane, Sierra de Pie de Palo, Argentina: Evidence of Rodinia rifting? In: Gondwana 12: Geological and Biological heritage of Gondwana, Abstracts (R.J. Pankhurst and G.D. Veiga, eds), p. 58. Academia Nacional de Ciencias, Córdoba, Argentina.

Bartholomew, M.J. and Tollo, R.P., 2004. Northern ancestry for the Goochland terrane as a displaced fragment of Laurentia. Geology, 32, 669-672.

Casquet, C., Baldo, E., Pankhurst, R.J., Rapela, C.W., Galindo, C., Fanning, C.M. and Saavedra, J., 2001. Involvement of the Argentine Precordillera Terrane in the Famatinian mobile belt: Geochronological (U-Pb SHRIMP)and metamorphic evidence from the Sierra de Pie de Palo. Geology, 29, 703-706.

Casquet, C., Rapela, C.W., Pankhurst, R.J., Galindo, C., Dahlquist, J., Baldo, E.G., Saavedra, J., González Casado, J.M. and Fanning, C.M., 2005a. Grenvillian massif-type anorthosites in the Sierras Pampeanas. J. Geol. Soc. Lond., 162, 9-12

Casquet, C., Pankhurst, R.J., Rapela, C.W., Fannning, C.M., Galindo, C. Baldo, E., González-Casado, J.M., Dahlquist, J. and Saavedra, J., 2005b.

The Maz suspect terrane: a new Proterozoic domain in the Western Sierras Pampeanas. In: Gondwana 12: Geological and Biological heritage of Gondwana (R.J. Pankhurst and G.D. Veiga, eds), p. 92. Academia Nacional de Ciencias, Córdoba, Argentina.

Casquet, C., Pankhurst, R.J., Fanning, C.M., Baldo, E., Galindo, C., Rapela C.W., González-Casado, J.M. and Dahlquist, J.A., 2006. U-Pb SHRIMP zircon dating of Grenvillian metamorphism in Western Sierras Pampeanas (Argentina): correlation with the Arequipa-Antofalla Craton and constraints on the extent of the Precordillera Terrane. Gondwana Res., 9, 524-529.
Cawood, P.A., Nemchin, A.A., Strachan, R.A., Kinny, P.D. and Loewy, S., 2004 Laurentian provenance and an intracratonic setting for the Moine Supergroup, Scotland, constrained by detrital zircons from the Loch Eil and Geln Urquhart successions. J. Geol. Soc. Lond., 161, 861-874.

Dahlquist, J.A., Pankhurst, R.J., Rapela, C.W., Casquet, C., Fanning, C.M., Alasino, P.H. and Baez, M., 2006. The San Blas Pluton: an example of the Carboniferous Plutonism in the Sierras Pampeanas, Argentina. J. South Am. Earth Sci., 20, 341-350.

Dalla Salda, L. and Varela, R., 1984. El metamorfismo en el tercio sur de la Sierra de Pie de Palo, San Juán. Rev Asoc. Geol. Arg., 39, 68-93.

Eby, G.N., 1990. The A-type granitoids: a review of their occurrence and chemical characteristics and speculations on their petrogenesis. Lithos, 26, 115-134.

Eby, G.N., 1992. Chemical subdivision of the A-type granitoids: petrogenetic and tectonic implications. Geology, $\mathbf{2 0}$, 641-644.

Galindo, C., Casquet, C., Rapela, C. Pankhurst, R.J., Baldo, E. and Saavedra, J., 2004. Sr, C and O isotope geochemistry and stratigraphy of Precambrian and Lower Paleozoic carbonate sequences from the Western Sierras Pampeanas of Argentina: tectonic implications. Precambr. Res., 131, 55-71.

Hoffman, P.F., 1991. Did the breakout of Laurentia turn Gondwanaland inside out? Science, 252, 1409-1412.

Holdaway, M. J., 2001. Recalibration of the GASP geobarometer in the light of recent garnet and plagioclase activity models and versions of the garnet-biotite geothermometer. Am. Mineral., 86, 117-1129.

Kebede, T. and Koeberl, C., 2003. Petrogenesis of A-type granitoids from the Wallagga area, western Ethiopia; constraints from mineralogy, bulk-rock chemistry, Nd and Sr isotopic compositions. Precambr. Res., 121, 1-24.

Kretz, R., 1983. Symbols for rock-forming minerals. Am. Mineral., 68, 277-279.

Leat, P.T., Jackson, S.E., Thorpe, R.S. and Stillman, C.J., 1986. Geochemistry of bimodal basalt-subalkaline/peralkaline rhyolite provinces within the Southern British Caledonides. J. Geol. Soc. Lond., 143, 259-273.

Lee, S.R., Cho, M., Cheong, C.S., Kim, H. and Wingate, M.T.D., 2003. Age, geochemistry, and tectonic significance of Neoproterozoic alkaline granitoids in the northwestern margin of the Gyeonggi Massif, South Korea. Precambr. Res., 122, 297-310.

Loewy, S.L., Connelly, J.N., Dalziel, I.W.D. and Gower, C.F., 2003. Eastern Laurentia in Rodinia: constraints from 
whole-rock $\mathrm{Pb}$ and $\mathrm{U} / \mathrm{Pb}$ geochronology. Tectonophysics, 375, 169-197.

Loewy, S.L., Connelly, J.N. and Dalziel, I.W.D., 2004. An orphaned basement block: the Arequipa-Antofalla Basement of the central Andean margin of South America. Geol. Soc. Am. Bull., 116, 171187.

Loizembauer, J., Wallbrecher, E., Fritz, H., Neumayr, P., Khudeir, A. and Kloetzli, U., 2001. Structural geology, single zircon ages and fluid inclusion studies of the Meatiq metamorphic core complex; implications for Neoproterozoic tectonics in the eastern desert of Egypt. Precambr. Res., 110, 357-383.

Ludwig, K.R., 2000. SQUID 1.00. A User's Manual. Berkeley Geochronology Centre, Special Publication 2

McDonough, M.R., Ramos, V.A., Isachsen, C.E., Bowring, S.A. and Vujovich, G.I., 1993. Edades preliminares de circones del basamento de la Sierra de Pie de Palo, Sierras Pampeanas occidentales de San Juán: sus implicancias para el supercontinente proterozoico de Rodinia. $12^{\circ}$ Cong. Geol. Argentino, Actas, 3, 340-342.

McMenamin, M.A.S. and McMenamin, D.L.S. 1990. The Energence of Animals; The Cambrian Breakthrough. Columbia University Press, New York, 217 pp.

Meert, J.G. and Torsvik, T.H., 2003. The making and unmaking of a supercontinent: Rodinia revisited. Tectonophysics, 375, 261-288.

Mushkin, A., Navon, O., Halicz, L., Hartmann, G. and Stein, M., 2003. The petrogenesis of A-type magmas from the Amran Massif, Southern Israel. J. Petrol., 44, 815-832.

Paces, J.B. and Miller, J.D., Jr, 1993. Precise U-Pb ages of Dulth complex and related mafic intrusions, northeastern Minnesota; geochronological insights to physical, petrogenetic, paleomagnetic and tectonomagnetic processes associated with the $1.1 \mathrm{Ga}$ Midcontinent Rift System. J. Geophys. Res. B, 98, 1399714013.

Pankhurst, R.J. and Rapela, C.W., eds, 1998. Introduction. In: The ProtoAndean Margin of Gondwana. Spec. Publ. Geol. Soc. Lond., 142, 1-9.

Paulsson, O. and Andreasson, P.G., 2002. Attempted break-up of Rodinia at 850
Ma; geochronological evidence from the Seve-Kalak superterrene, Scandinavian Caledonides. J. Geol. Soc. Lond., 159, 751-761.

Pease, V. and Bogdanova, S., 2003.

Rodinia's Baltica; internal structure and margins. Geol. Soc. Am. Abstr. Prog., 35, 343.

Piper, J.D.A., 1976. Palaeomagnetic evidence for a Proterozoic supercontinent. Philos. Trans. R. Soc. Lond., A280, 469490.

Pisarevsky, S.A., Wingate, M.T.D., Powell, C.M., Johnson, S. and Evans, D.A.D., 2003. Models of Rodinia assembly and fragmentation. In: Proterozoic East Gondwana: Supercontinent Assembly and Breakup (M. Yoshida, B.F. Windley and S. Dasgupta, eds). Spec. Publ. Geol. Soc. Lond., 206, 35-55.

Ramos, V.A., 2004. Cuyania, an exotic block to Gondwana: Review of a historical success and the present problems. In: Cuyania: An Exotic Block to Gondwana (G.I. Vujovich, L.A.D. Fernandes and V.A. Ramos, eds). Gondwana Res., 7, 1009-1026.

Ramos, V., Vujovich, G.I. and Dallmeyer, R.D., 1996. Los klippes y ventanas tectónicas pre-andicas de la Sierra de Pie de Palo (San Juán): Edad e implicaciones tectónicas. In: XIII Congreso Geológico Argentino y III Congreso de Exploración de Hidrocarburos, Actas, 5, 377-391.

Rapela, C.W., Pankhurst, R.J., Casquet, C., Fanning, C.M., Galindo, C. and Baldo, E., 2005. Datación U-Pb SHRIMP de circones detríticos en paraanfibolitas neoproterozoicas de la secuencia Difunta Correa (Sierras Pampeanas Occidentales, Argentina). Geogaceta, 38, 227-230.

Ravna, E.K., 2000. Distribution of $\mathrm{Fe}^{+2}$ and $\mathrm{Mg}$ between coexisting garnet and hornblende in synthetic and natural systems: an empirical calibration of the garnet-hornblende $\mathrm{Fe}-\mathrm{Mg}$ geothermometer. Lithos, 53, 265-277.

Scheepers, R., 2000. Granites of the Saldania mobile belt, South Africa: radioelements and $\mathrm{P}$ as discriminators applied to metallogeny. J. Geochem. Expl., 68, 69-86.

Shellnutt, J.G., Dostal, J. and Keppie, J.D., 2004. Petrogenesis of the $723 \mathrm{Ma}$ Coronation Sills, Amundsen Basin,
Arctic Canada; implications for the breakup of Rodinia. Precambr. Res., 129, 309-324.

Tera, F. and Wasserburg, G.J., 1972. $\mathrm{U}-\mathrm{Th}-\mathrm{Pb}$ systematics in three Apollo 14 basalts and the problem of initial $\mathrm{Pb}$ in lunar rocks. Earth Planet. Sci. Lett., 14, 281-304.

Thomas, W.A. and Astini, R.A., 2003. Ordovician accretion of the Argentine Precordillera terrane to Gondwana: a review. J. South. Am. Earth Sci., 16, 67-79.

Tollo, R.P., Aleinikoff, J.N., Bartholomew, M.J. and Rankin, D.W., 2004. Neoproterozoic A-type granitoids of the central and southern Applachians: intraplate magmatism associated with episodic rifting of the Rodinia supercontinent. Precambr. Res., 128, 3-38.

Vujovich, G.I., Van Staal, C.R. and Davis, W., 2004. Age constraints and the tectonic evolution and provenance of the Pie de Palo Complex, Cuyania composite terrane, and the Famatinian orogeny in the Sierra de Pie de Palo, San Juán, Argentina. Gondwana Res., 7, 10411056.

Wenli, L., Gao, S., Zhang, B., Li, H., Liu, Y and Cheng, J., 2003. Neoproterozoic tectonic evolution of the northwestern Yangtze Craton, South China; implications for amalgamation and break-up of the Rodinia supercontinent. Precambr. Res., 122, 111-140.

Williams, I. S., 1998. U-Th-Pb geochronology by ion microprobe. Rev. Econ. Geol., 7, 1-35.

Wingate, M.T.D., Campbell, I.H., Compston, W. and Gibson, G.M., 1998. Ion microprobe $\mathrm{U}-\mathrm{Pb}$ ages for Neoproterozoic-basaltic magmatism in south-central Australia and implications for the breakup of Rodinia. Precambr. Res., 87, 135-159.

Zhai, M., Shao, J., Hao, J. and Peng, P., 2003. Geological signature and possible position of the North China Block in the supercontinent Rodinia. Gondwana Res. 6, 171-183. 